\title{
Pelatihan Higiene dan Sanitasi Makanan pada Pedagang Makanan di Kantin SD
}

\author{
Jamilatur Rohmah'1, Siti Cholifah'2, Vanda Rezania ${ }^{3}$ \\ Universitas Muhammadiyah Sidoarjo. \\ Email: 1jamilaturrohmah@umsida.ac.id, 20holifah_siti79@yahoo.com, \\ 3vandarezania@umsida.ac.id
}

\begin{abstract}
The school canteen has an important role to fulfill the food needs of school children. In general, foods that are sold in canteens have very diverse variations, with prices relatively cheap and easily accessible to school children. The need for fulfillment of hygienic foods is ordered by the factors of place and hygiene of the food handlers need to be done. Foods that do not meet the requirements and safety that can be given due to health problems or diseases related to food such as diarrhea, cholera, dysentery, typhus, and other food poisoning. The number of food handlers in the cafeteria of SD Muhammadiyah 1 and 2 Sidoarjo competes 6 people. Based on the results of observations and interviews, they did not have sufficient educational background in terms of hygiene and food sanitation, and they never gained knowledge about food hygiene and sanitation. This will greatly determine the quality of food provided to consumers especially elementary school children. Based on this, the Community Service activities on hygiene training and food sanitation were carried out at food handlers in the cafeteria of Muhammadiyah 1 and 2 elementary schools in Sidoarjo.
\end{abstract}

Keywords: food hygiene and sanitation, food handlers, elementary school canteens.

\section{Pendahuluan}

Kantin sekolah merupakan tempat yang mempunyai peranan penting untuk memenuhi kebutuhan makanan jajanan anak sekolah. Makanan jajanan yang dijual di kantin sekolah pada umumnya mempunyai variasi yang sangat beragam, dengan harga yang relatif murah, dan mudah dijangkau oleh anak sekolah. Sehingga pemenuhan kebutuhan akan makanan jajanan yang higienis dipengaruhi oleh faktor sanitasi tempat dan higiene pedagang makanan perlu untuk dilakukan. Karena yang secara langsung berhubungan dengan makanan dan peralatan mulai dari tahap persiapan, pembersihan, 
pengolahan, pengangkutan sampai penyajian adalah pedagang makanan. ${ }^{1,2}$

Hygiene dan sanitasi makanan merupakan pengendalian terhadap 4 faktor, yaitu faktor tempat, bahan makanan, peralatan, dan orang (penjamah makanan/ pedagang). Sedangkan sanitasi makanan merupakan salah satu usaha pencegahan yang menitikberatkan pada kegiatan dan tindakan yang perlu untuk membebaskan makanan dan minuman dari segala bahaya yang dapat mengganggu kesehatan, mulai dari sebelum makanan diproduksi, selama dalam proses pengolahan, penyimpanan, pengangkutan, sampai pada saat dimana makanan dan minuman tersebut siap untuk dikonsumsikan kepada masyarakat atau konsumen. Dalam hal ini kantin sekolah dengan konsumennya sebagian besar adalah anak-anak. ${ }^{3,4}$

Hal serupa terjadi di Desa/Kelurahan Pucang Anom dan Lemahputro Sidoarjo karena disini terdapat Sekolah Dasar Muhammadiyah 1 \& 2 dan jumlah penduduknya yang cukup padat. Selain itu SD Muhammadiyah 2 lokasinya berdekatan dengan pasar tradisional. Jumlah pedagang makanan di kantin SD Muhammadiyah 1 dan 2 Sidoarjo berjumlah 6 orang. Dalam hal higiene dan sanitasi makanan, pada umumnya mereka tidak memiliki latar belakang pendidikan yang cukup. Hal ini tentu akan sangat mempengaruhi kualitas makanan yang disajikan kepada konsumen khususnya anak sekolah.

Berdasarkan hasil observasi dan wawancara kepada beberapa pedagang, mereka mengatakan tidak pernah mendapatkan pengetahuan khusus mengenai higiene dan sanitasi makanan, tidak pernah berusaha untuk membaca buku mengenai sanitasi makanan, serta tidak pernah

1 Departemen Kesehatan RI., Keputusan Menteri Kesehatan RI No. 942 Tahun 2003Tentang Persyaratan Higiene Sanitasi Makanan Jajanan (Jakarta. 2006).

2 Sudrajat, A., Kantin Sekolah. (https://akhmadsudrajat.wordpress.com/. Diakses tanggal 15 Oktober 2018).

3 Prabu., Penyimpanan dan Pengangkutan Makanan (Prinsip Food Hygiene) (http://putraprabu.wordpress.com/2009/01/05/penyimpanan-dan pengangkutanmakanan-prinsip-food-hygiene/. Diakses tanggal 02 Oktober 2018).

${ }^{4}$ Departemen Kesehatan RI., Persyaratan Higiene Sanitasi Rumah Makan dan JajananSekolah. (Jakarta. 2006). 
mendapatkan pelatihan yang berhubungan dengan higiene dan sanitasi makanan. Hal ini terlihat saat melayani pembeli (murid-murid) mereka tidak memperhatikan kebersihan, seperti tidak mencuci tangan saat mengambil makanan setelah sebelumnya melakukan kegiatan lain seperti mengambil uang, menggaruk kaki, dll. Hal ini akan sangat mempengaruhi kualitas makanan yang disajikan kepada konsumen khususnya anak SD. Karena makanan yang tidak memenuhi keamanan dan persyaratan mutu diantaranya dapat menimbulkan gangguan kesehatan atau penyakit bawaan makanan seperti disentri, diare, typhus, cholera, dan keracunan makanan lainnya. 5

Tindakan preventif dinilai sangat penting meskipun memang belum terdapat kasus keracunan yang disebabkan oleh makanan jajanan produksi kantin tersebut. Tindakan ini dimaksudkan untuk mencegah faktor risiko yang bisa saja muncul akibat higiene dan sanitasi yang kurang agar makanan jajanan kantin aman dikonsumsi dan mencegah kejadian penyakit bawaan makanan maupun keracunan yang disebabkan oleh makanan karena apabila makanan terkontaminasi oleh zat-zat yang berbahaya maka kasus keracunan makanan tidak dapat dihindari. ${ }^{6}$

\section{Metode}

Mekanisme pelaksanaan PPM higiene dan sanitasi pedagang makanan di kantin SD adalah sebagai berikut:

\section{Persiapan Pelatihan}

Sebelum kegiatan pelatihan higiene dan sanitasi makanan dilakukan pada para pedagang makanan di kantin SD Muhammadiyah 1 \& 2 Sidoarjo, terlebih dahulu tim pengusul mempersiapkan materi pelatihan. Kegiatan pelatihan dalam bentuk pendampingan dilaksanakan di rumah dan di

\footnotetext{
5 WHO., Penyakit Bawaan Makanan. (Jakarta: Buku Kedokteran EGC, 2005).

6 Hartono, A., Penyakit Bawaan Makanan: Fokus Pendidikan Kesehatan (Foodborne Disease: a focus for health education), (Jakarta. Penerbit Buku Kedokteran EGC, 2002).
} 
sekolah tempat para pedagang berjualan. Selain itu juga akan dilakukan forum diskusi yang akan dilaksanakan di aula sekolah bersama mitra, dan bekerjasama dengan kepala sekolah dan guru-guru SD Muhammadiyah 1 \& 2 Sidoarjo. Rencana implementasi kegiatan pendampingan tersebut mencakup: Mempersiapkan form penilaian hygiene dan sanitasi. Sedangkan untuk forum diskusi, rencana implementasinya yaitu:

a. Mempersiapkan materi atau powerpoint untuk pelatihan ke mitra.

b. Mempersiapkan pelatihan kit yang meliputi materi pelatihan, modul higiene dan sanitasi, ATK, dan blocknote.

c. Pembagaian tugas tim pelaksana untuk diskusi dan tanya jawab.

d. Mempersiapkan umpan balik pelatihan dalam bentuk kuisioner.

\section{Pelaksanaan Pelatihan Higiene dan Sanitasi}

Pelatihan ini dilakukan dengan melakukan pendampingan ke rumah dan sekolah tempat para pedagang berjualan. Tim pelaksana membawa format penilaian yang berhubungan dengan higiene dan sanitasi makanan yang digunakan untuk menilai selama proses pendampingan. Pendampingan ini dilakukan dua kali di rumah dan dua kali di sekolah kepada masing masing pedagang. Pada saat pendampingan di rumah yang pertama pelaksana mengamati cara pengolahan makanan yang biasa dibuat oleh pedagang untuk dijual di sekolah. Selama proses pengolahan pelaksana memberi penilaian berdasarkan formulir yang telah disiapkan. Selain proses pengolahan tim juga menilai perlengkapan dapur pedagang seperti tersedianya tempat pembuangan sampah, air bersih, adanya binatang pengganggu seperti tikus dan kecoa. Setelah selesai pengamatan, tim memberikan penjelasan mengenai higiene dan sanitasi makanan kepada peserta dengan tujuan adanya peningkatan pengetahuan dan keterampilan mengenai higiene dan sanitasi makanan. Selanjutnya akan dilakukan pendampingan kedua satu minggu berikutnya untuk mengamati 
dan menilai proses pengolahan makanan serta kebersihan lingkungan dapur. Sedangkan pendampingan di sekolah dilakukan guna mengamati dan menilai cara pedagang menyajikan makanan kepada konsumennya (anak SD). Pendampingan juga dilakukan dua kali, yang pertama tim melakukan pengamatan dan penilaian kemudian memberikan penjelasan mengenai hal yang berhubungan dengan kebersihan penyajian makanan serta dampak negatifnya dan dilanjutkan pendampingan yang kedua satu minggu berikutnya

\section{Hasil dan Diskusi}

Kegiatan program pengabdian masyarakat dengan pelatihan higiene dan sanitasi kepada pedagang makanan dikantin SD memberikan manfaat yang besar. Para pedagang makanan bersemangat mengikuti kegiatan ini sebagai bentuk untuk meningkatkan pengetahuan, sikap, dan perilaku mereka dalam hal higiene dan sanitasi makanan. Berdasarkan permasalahan yang dihadapi oleh mitra (pedagang makanan di kantin SD Muhammadiyah 1 dan 2 Sidoarjo) maka kegiatan program PPM dilaksanakan dalam bentuk pelatihan dengan melakukan pendampingan. Pendampingan yang dilakukan dilaksanakan di rumah pedagang dan di kantin sekolah tempat para pedagang berjualan selama bulan Januari sampai April 2019.

Selama proses pendampingan, tim pelaksana membawa form penilaian tentang hygiene dan sanitasi makanan yang digunakan untuk menilai kondisi hygiene dan sanitasi makanan para pedagang. Tim pelaksana pada saat pendampingan di rumah yang pertama, melakukan pengamatan cara pengolahan makanan yang biasa dilakukan oleh pedagang. Serta melakukan penilaian berdasarkan form penilaian yang telah disiapkan. Selain proses pengolahan tim juga menilai perlengkapan dapur pedagang seperti tersedianya tempat pembuangan sampah, air bersih, adanya binatang pengganggu seperti tikus dan kecoa. Setelah selesai pengamatan, tim 
memberikan penjelasan mengenai higiene dan sanitasi makanan kepada peserta dengan tujuan adanya peningkatan pengetahuan dan keterampilan mengenai higiene dan sanitasi makanan. Serta memberikan penjelasan dampak negatif penggunaan bahan makanan yang kurang baik dan pengolahan makanan yang kurang bersih.

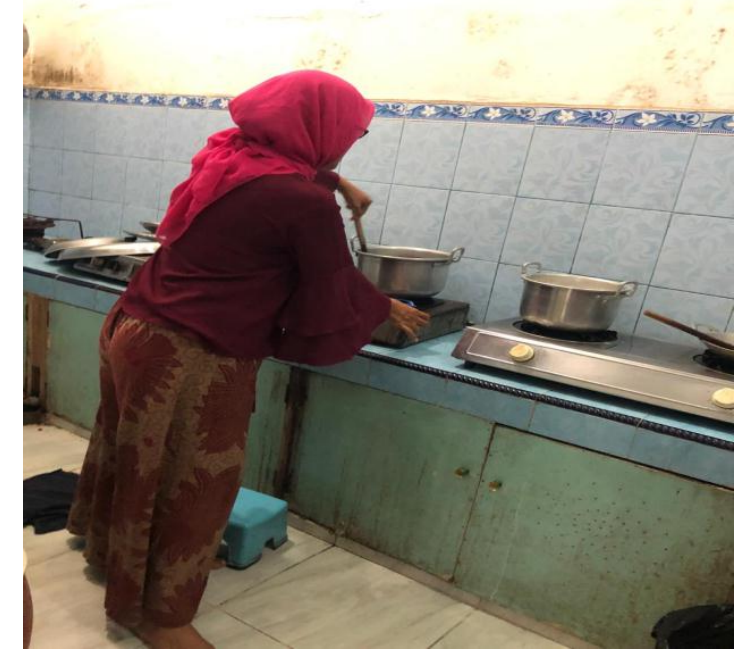

Gambar 1. Pendampingan di rumah (Sumber: Dokumentasi, 2019)

Kemudian dilakukan pendampingan di sekolah dilakukan guna mengamati dan menilai cara pedagang menyajikan makanan kepada konsumennya (anak SD). Kegiatan pelatihan selain dilakukan dalam bentuk pendampingan di rumah dan di sekolah, juga dilakukan dengan mengumpulkan seluruh pedagang dalam satu ruangan untuk melakukan diskusi mengenai pelaksanaan, hambatan dan kesulitan dalam hygiene dan sanitasi. Berdasarkan proses pendampingan yang dilakukan dapat diketahui adanya perubahan pengetahuan dan keterampilan para pedagang dalam hal hygiene dan sanitasi makanan. Perubahan tersebut diantaranya: kondisi lingkungan dapur menjadi lebih bersih, pemilihan bahan-bahan makanan yang baik, mencuci tangan setelah memegang uang, menggunakan sarung tangan plastik/ sendok/ penjepit makanan dalam mengolah dan menyajikan 
makanan, mencuci tangan setelah menggaruk kepala atau kaki saat berjualan, dan menggunakan apron/celemek pada saat mengolah makanan dan berjualan di kantin sekolah.

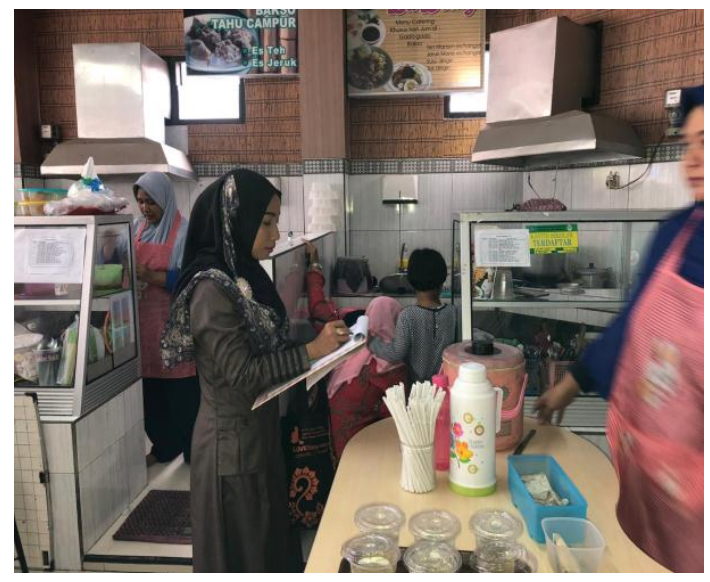

Gambar 2. Pendampingan di kantin sekolah (Sumber: Dokumentasi, 2019)

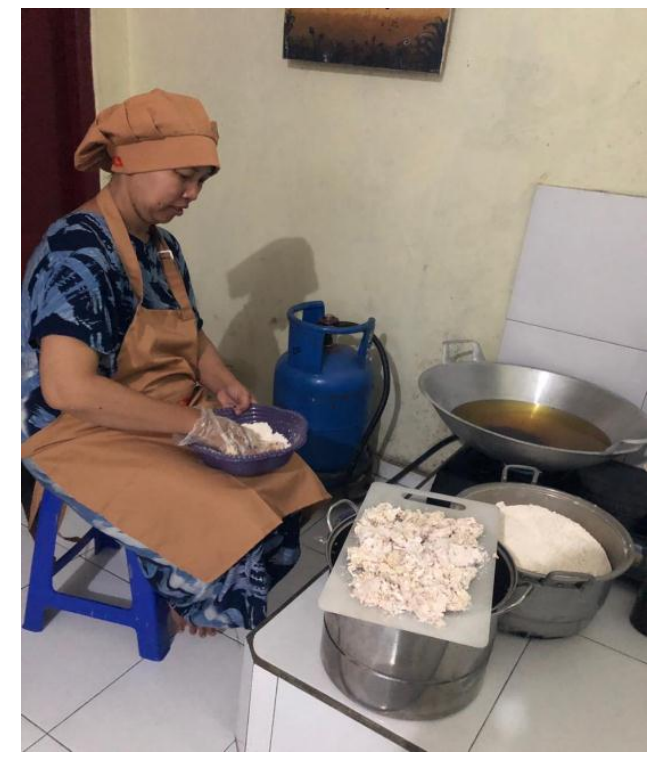

Gambar 3. Perubahan setelah pendampingan pertama di rumah (pedagang A) (Sumber: Dokumentasi, 2019) 


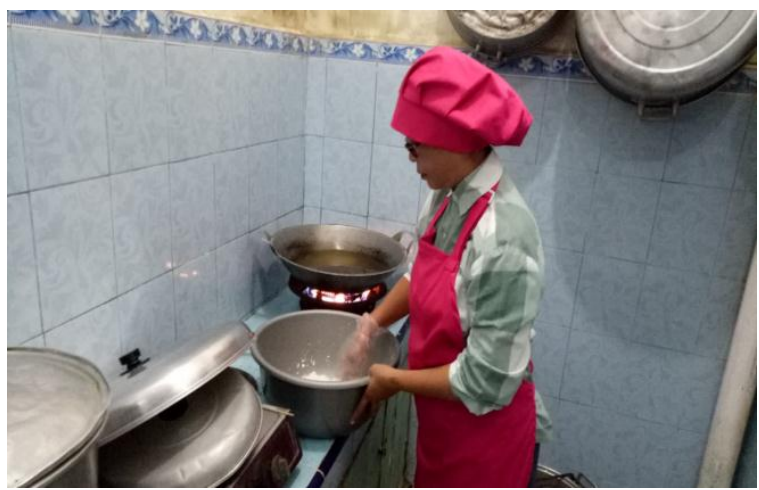

Gambar 4. Perubahan setelah pendampingan pertama di rumah (pedagang B) (Sumber: Dokumentasi, 2019)

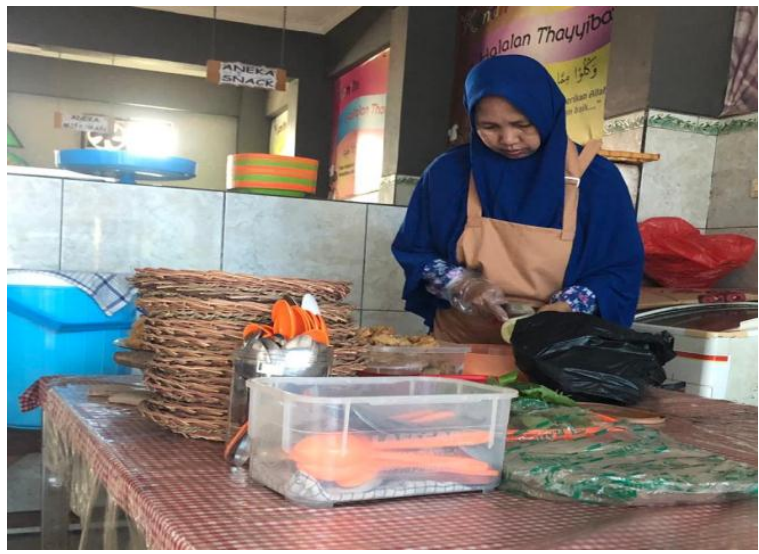

Gambar 5. Perubahan setelah pendampingan pertama di sekolah (Sumber: Dokumentasi, 2019)

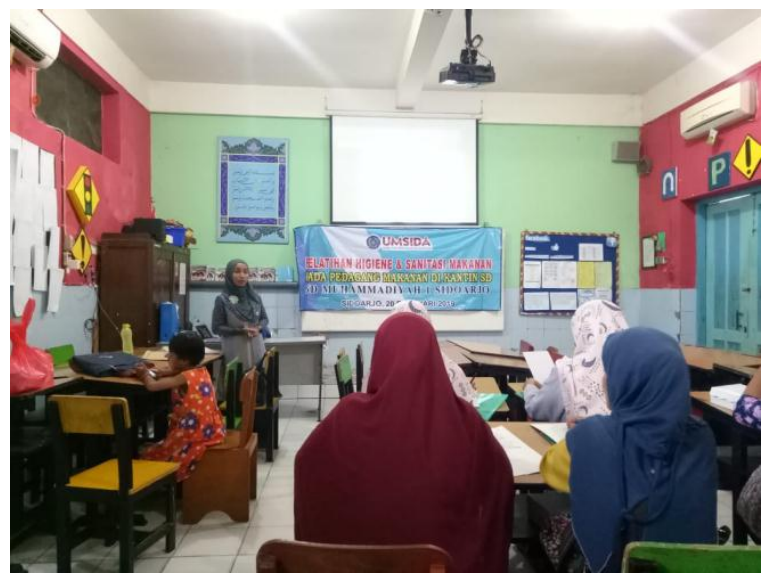

Gambar 6. Forum diskusi hygiene dan sanitasi (Sumber: Dokumentasi, 2019) 
Selama proses pendampingan diketahui bahwa sebagian besar pedagang memiliki pengetahuan dan keterampilan yang kurang baik mengenai hygiene dan sanitasi makanan. Mereka mengatakan tidak pernah mendapatkan pelatihan khusus mengenai higiene dan sanitasi makanan sehingga tidak mengetahui dampak negatif yang ditimbulkan akibat pengolahan makanan yang kurang baik. Meskipun mereka sedikit susah mengubah kebiasaan tetapi mereka akan berusaha untuk selalu menjaga kebersihan dalam pengolahan dan penyajian makanan yang dijual.

\section{Simpulan}

Pelatihan hygiene dan sanitasi makanan guna meningkatkan pengetahuan dan keterampilan pedagang makanan di kantin SD telah terlaksana dan dapat diterima dengan baik oleh mitra. Edukasi semacam ini sangat penting dilakukan untuk memahamkan pentingnya hygiene dan sanitasi makanan. Sehingga pada kegiatan ini dapat disimpulkan:

1. Meningkatnya pengetahuan dan keterampilan para pedagang makanan di kantin SD tentang hygiene dan sanitasi makanan.

2. Meningkatnya keterampilan para pedagang makanan di kantin SD mengenai hygiene dan sanitasi makanan baik dalam hal pengolahan maupun dalam penyajian makanan.

\section{Daftar Referensi}

Departemen Kesehatan RI. 2006. Keputusan Menteri Kesehatan RI No. 942 Tahun 2003 Tentang Persyaratan Higiene Sanitasi Makanan Jajanan. Jakarta.

Departemen Kesehatan RI. 2006. Persyaratan Higiene Sanitasi Rumah Makan dan Jajanan Sekolah. Jakarta.

Hartono, A. 2002. Penyakit Bawaan Makanan: Fokus Pendidikan Kesehatan (Foodborne Disease: a focus for health education), Jakarta. Penerbit Buku Kedokteran EGC.

Prabu. 2009. Penyimpanan dan Pengangkutan Makanan (Prinsip Food 
Hygiene)

http://putraprabu.wordpress.com/2009/01/05/penyimpanan-dan pengangkutan-makanan-prinsip-food-hygiene/. Diakses tanggal 02 Oktober 2018.

Sudrajat, A. 2010. Kantin Sekolah. https://akhmadsudrajat.wordpress.com/. Diakses tanggal 15 Oktober 2018.

WHO. 2005. Penyakit Bawaan Makanan. Jakarta: Buku Kedokteran EGC. 